\title{
Working
}

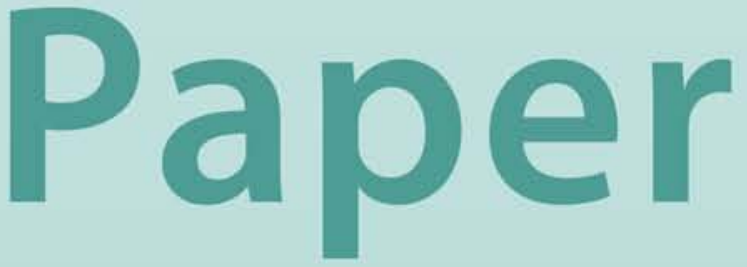




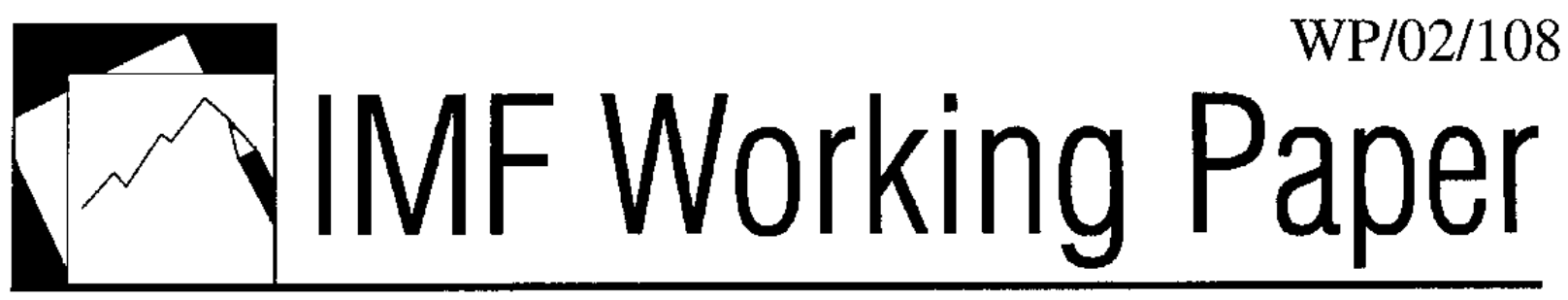

\section{Experience with Budgetary Convergence in the WAEMU}

Ousmane Doré and Paul R. Masson 


\title{
IMF Working Paper
}

African Department and Policy Development and Review Department

\section{Experience with Budgetary Convergence in the WAEMU}

Prepared by Ousmane Doré and Paul R. Masson ${ }^{1}$

Authorized for distribution by Elliott Harris

June 2002

\begin{abstract}
The views expressed in this are those of the author(s) and do not necessarily represent those of the IMF or IMF policy. Describe research in progress by the author(s) and are published to elicit comments and to further debate.
\end{abstract}

This paper reviews the experience of fiscal adjustment undertaken in the West African Economic and Monetary Union (WAEMU) countries since the entry into force of the 1994 treaty establishing the framework for a regional convergence of national fiscal policies. We propose a measure of the structural deficit that corrects for movements of both the business cycle and terms of trade. Though the fiscal deficit worsened in 1998-2001 in some countries because of terms of trade deterioration and unfavorable movements in the business cycle, convergence stalled even when corrected for these factors. Meeting fiscal deficit targets in the future will be facilitated by a favorable external environment but, in any case, will require a higher revenue ratio and downward pressure on government wages as shares of GDP.

JEL Classification Numbers:B22, C12, C13, E62

Keywords: Fiscal policy, Convergence, Integration

Authors' E-Mail Addresses: Odore@imf.org and Pmasson@imf.org

${ }^{1}$ A version of this paper was presented at the fortieth anniversary Conference of the Central Bank of West African States (BCEAO), May 13-14, 2002. It was earlier presented at an IMF African Department lunchtime seminar; the authors are grateful for comments received from their colleagues. 


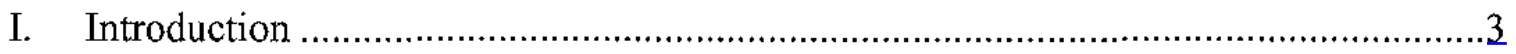

II. Assessment of Convergence Mechanism .................................................... $\underline{5}$

III. Why Have the Criteria Not Been Met? .............................................................

IV. Does the Elimination of Monetary Assistance Have Implications for Maintenance of Fiscal Discipline Within the Union? .................................16

V. What Leeway Is There for Achieving the Deficit Objective in the Future? ..............17

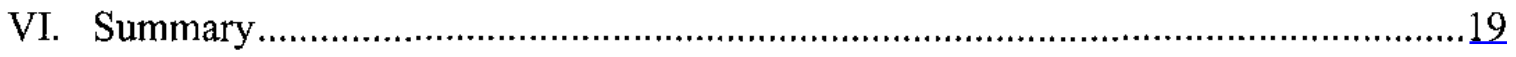

Annex I: Panel Regressions for WAEMU's Fiscal Adjustment ....................................21

Text Table

1. WAEMU: Budgetary Convergence Criteria, 1995-2001 …....................................

Figures

1. WAEMU: Unweighted Average Deficit and Standard Deviation ................................

2. WAEMU: Deviations from Targets for Secondary Criteria …................................... 8

3. WAEMU: Budget Balance, GDP, Growth, and Changes in Terms of Trade................11

4. WAEMU: Cyclical Position and Terms of Trade .....................................................14

5. WAEMU: Effects of Cycle and Terms of Trade on Budget Balance ...........................15

Annex Tables

A1. WAEMU: Panel Regression of Fiscal Balance (Ratio to GDP) on Output Gap and Terms of Trade, 1995-2001 ....................................................23

A2. WAEMU: Panel Regression of Government Revenue (Ratio to GDP) Output Gap and Terms of Trade, 1995-2001 ..................................................24

A3. WAEMU: Panel Regression of Government Expenditures (Ratio to GDP) on Output Gap and Terms of Trade, 1995-2001 ..........................................25

A4. WAEMU: Correlation Between Rate of Change of Output and Rate of

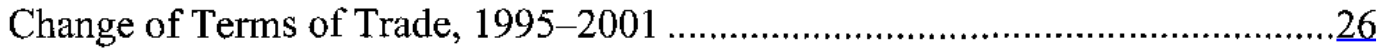

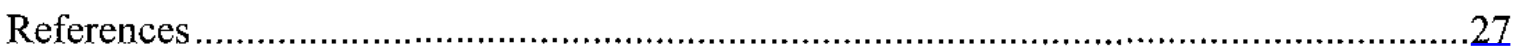




\section{INTRODUCTION}

The viability of any economic integration plan depends upon its ability to ensure the consistency of the economic and financial policies defined by individual member countries of the union with the corresponding policies of the other members and guarantce sustained convergence of the members' economic performance. This is especially true in the context of a monetary union, in which the existence of a common currency and common monetary policy exerts even more stringent constraints on national economic policies. In the WAEMU ${ }^{2}$ context, where the CFA franc is pegged to the euro and the autonomy of monetary policy and the ability to use the interest rate as an instrument are, therefore, limited, fiscal policies are of prime importance. They must be coordinated and be consistent with the maintenance of a fixed exchange rate over the medium term, even if they reflect differences in economic conditions over the short term. Lack of economic policy coordination can lead to negative externalities and, therefore, to policy changes in response to shocks that could jeopardize the common monetary policy.

Since the devaluation of their currency in 1994, member states of the WAEMU have collectively become aware that fiscal consolidation is essential to their adjustment process. To mitigate the risks posed by uncoordinated fiscal policies, they established in 1994 a multilateral surveillance system aimed at ensuring greater economic policy cohesiveness among the member states. As a community mechanism for economic policy control in the WAEMU member states, multilateral surveillance is based on the formulation of a set of core rules and standards for national economic policies to encourage economic convergence, defined as a reduction of the differences between the economic performances of member states.

The following criteria were established within the framework of the Convergence, Stability, Growth, and Solidarity Pact adopted by WAEMU governments in 1999:

- an average annual inflation rate of no more than 3 percent, based on the objective of keeping the inflation differential small between the WAEMU and the euro area;

\footnotetext{
${ }^{2}$ Established in 1994, the West African Economic and Monctary Union (WAEMU) consists of eight countries: Benin, Burkina Faso, Côte d'Ivoire, Guinea-Bissau, Mali, Niger, Senegal, and Togo. These countries have a common stable and convertible currency - the CFA franc-which has been pegged to the French franc since 1948 and to the euro since 1999. In addition to the common central bank (the BCEAO), the WAEMU institutions include the WAEMU Commission, the Banking Commission, and the regional stock exchange. In recent years, WAEMU countries have taken important steps toward greater regional integration and coordination of macroeconomic policies by adopting convergence criteria, establishing a common external tariff, and harmonizing taxes.
} 
- a basic fiscal balance (defined as nongrant revenue minus expenditure excluding foreign-financed investment)-to-GDP ratio that is zero or positive, based on the nced to strengthen fiscal sustainability;

- an overall debt-to-GDP ratio of less than 70 percent, based on the need to prevent public debt in the Union from increasing to levels that would disrupt the proper functioning of financial markets; and

- no change or a decrease in domestic and external payment arrears, based on the need to avoid alternative nonmarket financing of public deficits.

These so-called first-order criteria are supplemented with second-order indicators related to the wage bill (which should be less than 35 percent of tax receipts), the ratio of domestically financed investment to tax receipts (over 20 percent), the tax receipts-to-GDP ratio (over 17 percent), and the external current account deficit, excluding grants (less than 3 percent of GDP).

As can be seen, the convergence criteria applied since 1999 pay special attention to the constraints on public deficit and public debt sustainability, because unsustainable budget deficits and excessive indebtedness can increase the pressure for monetary financing and undermine the viability of the common currency. The setting of budgetary norms is also predicated on the belief that fiscal consolidation will lead to sustainable growth by freeing up resources for the private sector. Indeed, the pegging of the CFA franc to the euro at a fixed exchange rate considerably reduces the risk of capital loss for investors. In these circumstances, the yield of an asset depends on the size of the borrower's default risk and the intrinsic profitability of the asset in question. Lenders will therefore pay particular attention to the basic indicators of internal balance, namely, the stock of debt and the borrowing requirements of the government.

While the regional convergence pact reinforces the framework for fiscal discipline in the zone, a question arises as to whether it might also constrain the scope for countercyclical fiscal policy. In addition to the effect of the business cycle, a number of other factors, such as terms of trade fluctuations in the context of developing countries could explain why fiscal reference values may be breached. This paper aims at assessing the extent to which cyclical variations and terms of trade fluctuations may have affected the WAEMU's experience with the convergence mechanism since 1994. The analysis of the factors underlying fiscal slippages in the zone is particularly important in the current context, in which it is proposed to eliminate the monetary financing of public deficits. Our estimation indicates that, on average, a 1 percent shortfall of output from potential worsens the fiscal balance by 0.3 percent of GDP in the WAEMU; for the terms of trade, the effect of a 1 percent decline on the fiscal balance would be on the order of 0.08 percent.

The next section provides an assessment of the convergence mechanism, followed by an analysis of the factors that have influenced outcomes for the criteria (Section III). Section IV 
examines the question of whether the planned elimination of the monetary financing of budget deficits will foster fiscal discipline. Section $V$ discusses the possible leeway for achieving the deficit objective in the future, and Section VI concludes.

\section{Assessment of Convergence Mechanism}

Experience suggests that the convergence criteria and associated regional surveillance process have contributed to fiscal consolidation in the WAEMU (Table 1). However, while substantial progress was made during an initial period (1994-97), there has been a marked slowdown in fiscal convergence among member states since 1998. An examination of developments in the overall fiscal balance (excluding grants) in member states of the Union shows that the standard deviation around the unweighted mean tended to decline up to 1997 before starting to increase again in recent years (Figure 1), which tends to confirm a greater divergence in the degree of fiscal performances among countries recently. This observation is corroborated by developments in the unweighted average deficit for the seven WALMU countries: after a sharp improvement up to 1997, the deficit once again widened during the period 1998-2001.

Performances during the period 1994-97 show that considerable efforts were made toward fiscal consolidation in the WAEMU. The analysis of developments related to the key criterion (basic fiscal balance) over this period shows that the balance improved considerably, even though it generally remained negative for all member states. A better public expenditure structure was obtained because of better control of current primary expenditure, especially that related to the wage bill, which declined from 55.5 percent of tax revenue for the WAEMU as a whole in 1994 to 37.2 percent in 1998. During this period, all the countries recorded sharp declines in the share of wage bill in terms of tax receipts, and only two countries (Niger and Togo) were above the regional norm, set at 40 percent in 1998. The control of the wage bill had a positive impact on the contribution of domestic resources to investment. For the Union as a whole, the ratio of investment spending to tax revenues rose from 11 percent in 1994 to about 21 percent in 1998 , compared with a regional norm of 20 percent. Domestic and external payment arrears were also reduced during the period.

Since 1998, there has been a sharp reversal of these trends. The performances of the Union's member states during the period 1998-2001 show a worsening in the unweighted average for the overall fiscal balance (excluding grants), from -3.9 percent in 1998 to -4.8 percent for the Union as a whole. Although this worsening occurred in the context of a slowdown in real growth in the zone, it is also clear that expenditure controls were relaxed. This is evidenced by developments related to the three secondary fiscal criteria during the period 1998-2001 (see Figure 2). As regards the wage bill, not only did the average for the Union grow from 37.2 percent of tax receipts in 1998 to 37.9 percent in 2001, but only three countries (Benin, Mali, and Senegal) were in compliance with the regional norm at end-2001, compared with five at end-1998. The ratio of domestically financed investment to tax receipts improved slightly for the Union as a whole during the period, but this general trend masks sizable disparities between countries. Indeed, only Burkina Faso and Mali were in conformity with the regional norm of 20 percent throughout the period. There was no perceptible improvement over the period in the tax ratio, which averaged about 15 percent of GDP, with increasing divergence among countries. 
Table 1. WAEMU: Budgetary Convergence Criteria, 1995-2001

\begin{tabular}{|c|c|c|c|c|c|c|c|}
\hline & 1995 & 1996 & 1997 & 1998 & 1999 & 2000 & 2001 \\
\hline \multicolumn{8}{|c|}{ Basic fiscal balance $(>=0) \mathrm{l} /$} \\
\hline Benin & -0.8 & 1.4 & 1.5 & 3.8 & 2.8 & 2 & 0.6 \\
\hline Burkina Faso & 8.6 & 0.6 & 0.1 & -0.3 & -0.4 & -1.4 & -1.2 \\
\hline Côte d'Tvoire & -1.2 & 0.5 & -0.6 & -0.3 & -1.5 & -0.2 & 1.7 \\
\hline Guinea Bissau & -2.8 & -5.3 & -1 & -16.3 & -8.6 & -0.7 & -3.6 \\
\hline Mali & 0.1 & 2,2 & 1 & 1.2 & 0.1 & -0.8 & -1.3 \\
\hline Niger & -3.7 & -1.7 & -3.6 & -3.1 & -5.1 & -1.3 & -1.2 \\
\hline Senegal & -0.1 & 1.7 & 2.2 & 2.6 & 1.5 & 1.4 & 1.4 \\
\hline Togo & -4.3 & -2.5 & -1.4 & -3.8 & -1.9 & -3.4 & -1.9 \\
\hline WAEMU & -0.3 & 0.6 & 0 & 0.2 & -0.6 & -0.1 & 0.3 \\
\hline \multicolumn{8}{|c|}{ Wages and salaries/fiscal revenue $(<=35 \%)$} \\
\hline Benin & 43.8 & 40.8 & 39.0 & 35.4 & 33.2 & 32.0 & 31.8 \\
\hline Burkina Faso & 48.1 & 43.4 & 40.7 & 39.2 & 41.7 & 42.9 & 38.8 \\
\hline Côte d'Ivoire & 32.0 & 37.4 & 36.7 & 36.4 & 37.0 & 41.6 & 42.8 \\
\hline Guinea Bissau & 40.4 & 46.7 & 39.1 & 126.7 & 53.9 & 60.0 & 56.5 \\
\hline Mali & 36.5 & 28.9 & 28.9 & 27.4 & 27.8 & 31.3 & 29.3 \\
\hline Niger & 80.1 & 48.8 & 56.6 & 49.8 & 46.9 & 43.8 & 35.2 \\
\hline Senegal & 47.7 & 44.0 & 40.0 & 37.0 & 33.9 & 32.7 & 32.1 \\
\hline Togo & 59.0 & 54.6 & 50.3 & 51.2 & 51.2 & 54.9 & 52.0 \\
\hline WAEMU & 42.9 & 40.5 & 38.4 & 37.2 & 36.8 & 38.7 & 37.9 \\
\hline \multicolumn{8}{|c|}{ Capital expenditure domestically financed/fiscal revenuc $(>=20 \%)$} \\
\hline Benin & 10.7 & 5.1 & 7.5 & 8.2 & 11.0 & 15.0 & 21.5 \\
\hline Burkina Faso & 8.2 & 11.3 & 23.9 & 25.3 & 20.8 & 23.7 & 25.3 \\
\hline Côte d'Ivoire & 14.7 & 15.9 & 21.7 & 26.7 & 17.6 & 9.7 & 4.9 \\
\hline Guinea Bissau & 3.2 & 16.7 & 16.1 & 80.0 & 64.8 & 20.6 & 17.6 \\
\hline Mali & 14.1 & 14.1 & 16.3 & 20.2 & 22.2 & 25.7 & 23.7 \\
\hline Niger & 3.9 & 5.3 & 7.2 & 9.1 & 15.8 & 6.9 & 13.9 \\
\hline Senegal & 10.8 & 11.3 & 14.3 & 17.9 & 22.7 & 19.8 & 20.1 \\
\hline Togo & 9.6 & 4.4 & 2.9 & 6.3 & 1.8 & 3.1 & 3.2 \\
\hline WAEMU & 11.8 & 12.1 & 17.6 & 21.3 & 18.2 & 14.6 & 13.9 \\
\hline \multicolumn{8}{|c|}{ Fiscal revenue/GDP $(>=17 \%)$} \\
\hline Benin & 12.3 & 12.6 & 12.6 & 13.3 & 13.6 & 14.6 & 14.5 \\
\hline Burkina Faso & 10.8 & 11.5 & 12.1 & 12.4 & 12.8 & 12.8 & 13.8 \\
\hline Côte d'Ivoire & 18.0 & 19.0 & 17.9 & 16.9 & 16.8 & 16.2 & 16.5 \\
\hline Guinea Bissau & 6.9 & 6.8 & 7.7 & 3.7 & 8.6 & 10.9 & 9.5 \\
\hline Mali & 11.1 & 13.1 & 13.8 & 13.9 & 14.1 & 12.9 & 14.8 \\
\hline Niger & 6.6 & 6.7 & 8.2 & 9.1 & 9.9 & 10.6 & 11.9 \\
\hline Senegal & 14.8 & 15.6 & 15.7 & 16.0 & 16.8 & 17.3 & 17.1 \\
\hline Togo & 13.6 & 13.1 & 13.0 & 13.8 & 12.8 & 12.0 & 12.2 \\
\hline WAEMU & 14.4 & 15.2 & 15.1 & 14.9 & 15.1 & 14.9 & 15.4 \\
\hline
\end{tabular}

Sources: WAEMU Commission; national authorities; and staff estimates.

1/ Total revenue, excluding grants minus total expenditures, excluding foreign-financed investment outlays. 


\section{Figure 1. WAEMU: Unweighted Average Deficit and Standard Deviation}

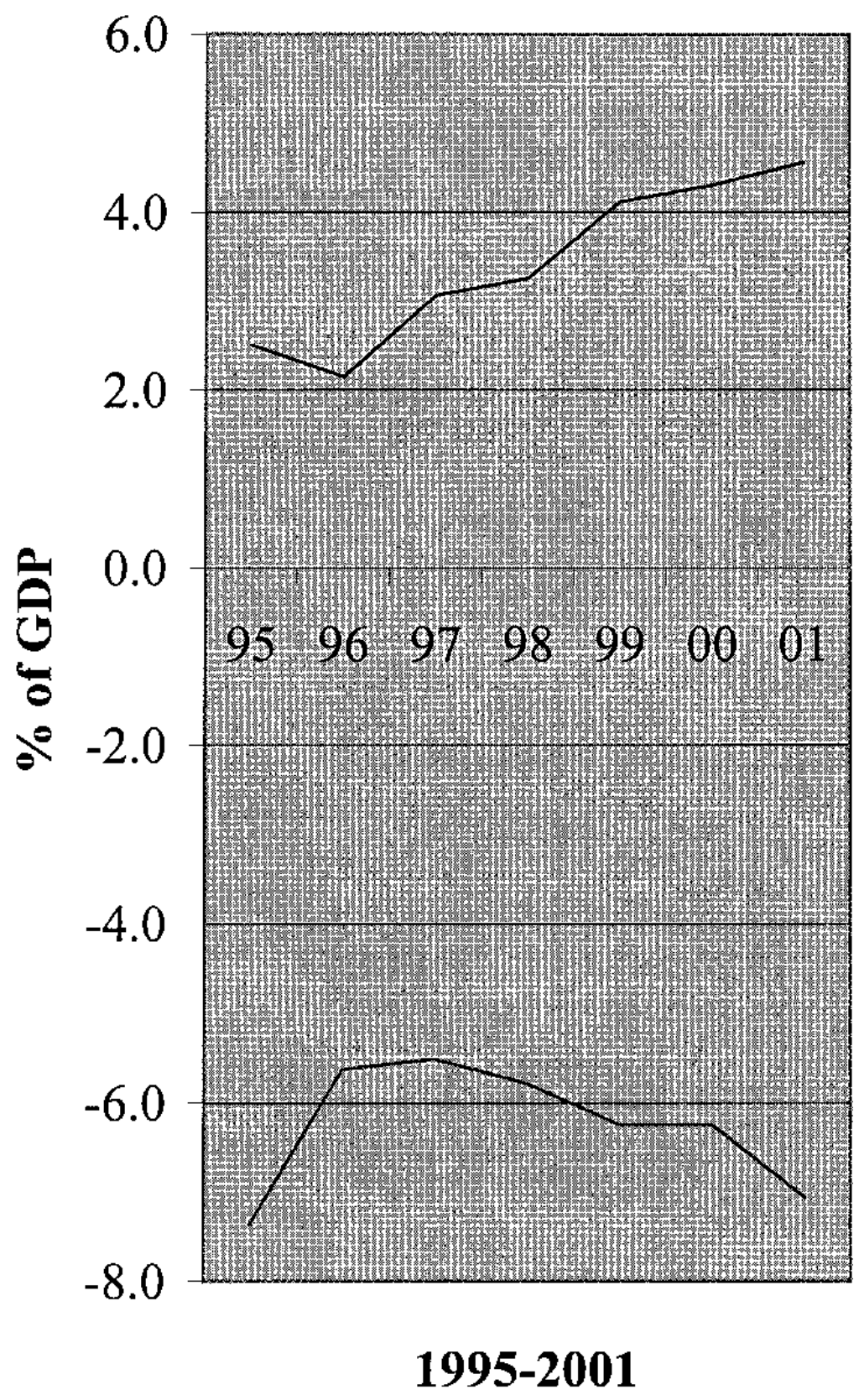

— standard deviation - mean 


\section{Figure 2. WAEMU: Deviations from Targets for Secondary Criteria}

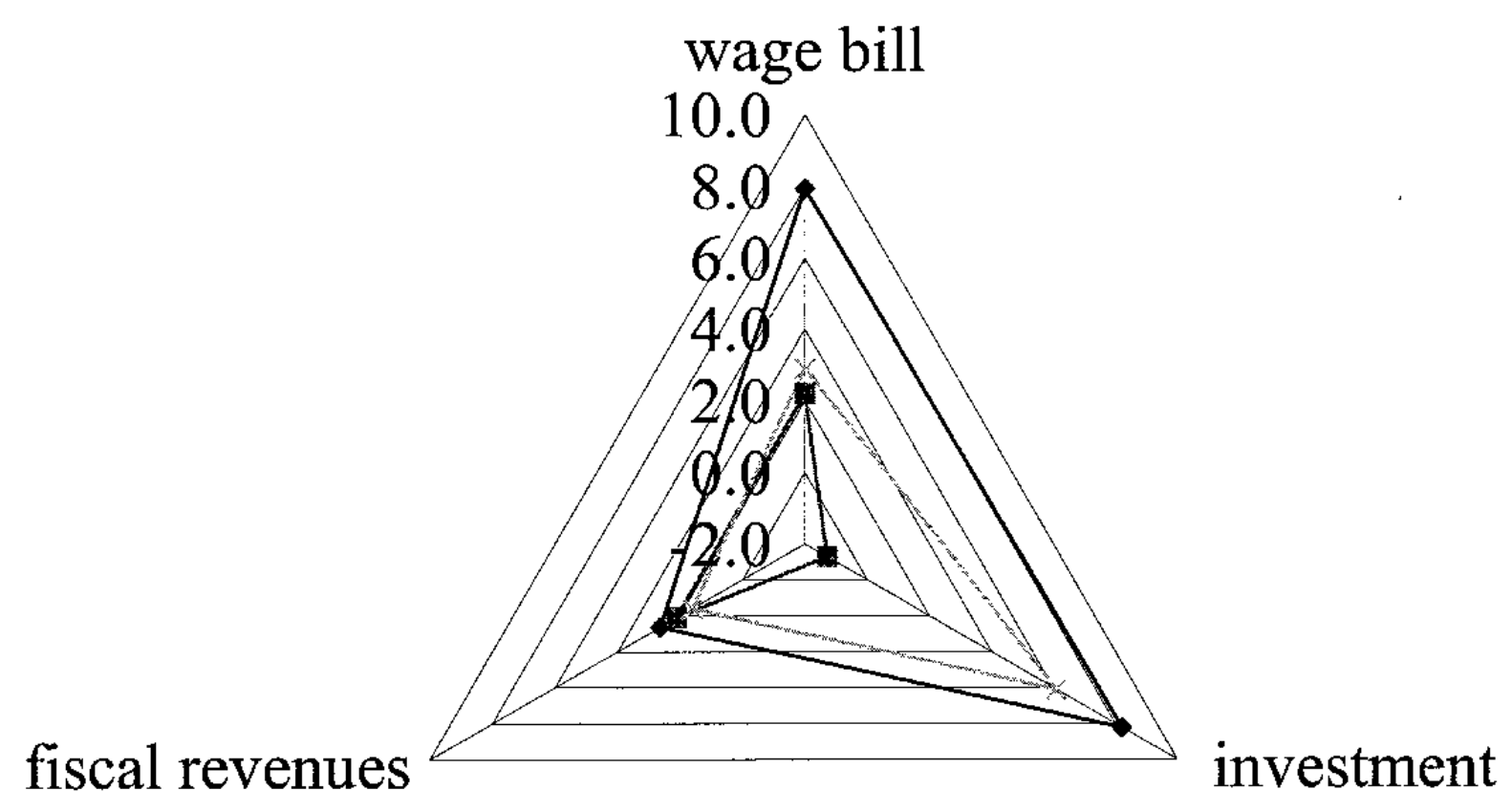


In light of the above, the cause of divergences among the countries still needs to be clarified, as a number of factors make it difficult to distinguish between convergence effects and those that encourage divergence among economies in the process of integration. Historical experience and recent theoretical research highlight the observation that regional arrangements among developing countries (south-south integration) tend to widen the gap between the poorest and the least poor countries, unlike north-north arrangements, where the less developed countries (e.g., Spain, Greece, Ireland, and Portugal, in the case of the European Union) tend to converge toward the income levels of their richer partners, such as France and Germany. But it is difficult to ascertain to what extent convergence is the result of underlying economic forces or the consequence of policies, including compensatory assistance from the richer states (no such mechanism exists in the WAEMU).

\section{Why Have the Criteria Not Been Met?}

As noted above, an examination of economic developments in the WAEMU countries seems to reveal two adjustment phases: during the period 1995-97, growth was strong and fiscal balances improved; by contrast, from 1998 onward there was far less progress on the fiscal side and, indeed, a reversal, while growth was slower. Figure 2 shows that this observation also applies to two of the three secondary criteria when considering the WAEMU as a whole: for investment and the wage bill, deviations from the target were limited in the first period but have expanded since $1999 .^{3}$ As regards the tax revenue-to-GDP ratio, more lasting progress was achieved, as receipts climbed from 14 percent of GDP in 1995 to about 15 percent in 1999 on average, but this figure is still well below the target of 17 percent. Since 1994, there has also been a decline in the stock of public debt, which has, however, remained above the ceiling of 70 percent of GDP. In sum, the deterioration in the fiscal balance is attributable to a series of slippages in one of the primary criterion (debt) and the secondary criteria (revenue and wages). Paradoxically, the real progress made in boosting investment also contributed to the worsening of the fiscal balance.

This issue can be analyzed more thoroughly by attempting to link these slippages to economic or political causes. Were there factors external to the region that could explain the poor fiscal performance? Were there political factors in some countries that may have influenced developments related to the criteria?

A standard approach to the calculation of structural deficits is to correct for the cyclical position of the economy; this is routinely done for industrial countries using an "output gap" concept. We, therefore, first establish the correlation, country by country, between the fiscal balance and the GDP growth rate (or, corresponding to an output gap, the cumulative growth rate, net of the average for the period 1995-2001). This leads to a distinction between those countries for which

\footnotetext{
${ }^{3}$ In Figure 2, the deviations from the criteria have been calculated such that a positive deviation indicates a worse outcome (e.g., for investment, it indicates an investment level below the target, while, for the wage bill, it corresponds to a level in excess of the target).
} 
the correlation is strong and positive (Benin, Mali) and those for which, on the contrary, it is decidedly negative (in this case, only Côte d'Ivoire) - that is, goes in the wrong direction. These results suggest that correcting for the output gap is insufficient in the case of these developing countries. Indeed, instead of using the output gap, we examined the correlations between the terms of trade and the fiscal balance, using both the rates of growth and the levels of the terms of trade. (The latter variable gave the most satisfactory results). These correlations are much stronger than for the output gap: there are large, positive correlations for all the countries (ranging up to 0.81 and 0.94 for Benin and Burkina Faso, respectively), except Côte d'Ivoire and Togo. A further advantage of using the terms of trade is that they are closer to being exogenous than GDP in the case of small, open economies. The countries of the region certainly have limited power over their terms of trade, since typically their exports are primary commodities priced on world markets and their imports are manufacturing goods produced by industrial countries. When the two variables are included together in a regression, both are significant (see below).

It therefore seems that much of the change in fiscal balances results from movements in the terms of trade, over which the countries of the region have little control (also see Figure 3 ). The two exceptions, in contrast, can be explained by political events that strongly influenced the macroeconomic performances of the countries concerned. The political crisis in Côte d'Ivoire in 1999-2000 curtailed growth and cut off access to external financing, and these developments had the effect of shrinking the budget deficit. Paradoxically, this allowed Côte d'Ivoire to remain below the deficit ceiling, but it explains why a normal correlation between the fiscal balance and growth or the terms of trade does not apply to that country. Togo has also experienced a political crisis since 1998, leading to the curtailment of external financial assistance, as a result of which it could not generate larger deficits despite the slow economic growth.

Tables A1, A2 and A3 of the Annex show the results of an estimation with fixed effects, based on panel data for the seven countries (excluding Guinea-Bissau) over the period 1995-2001. The observations covering the period 1999-2001 for Côte d'Ivoire and Togo were excluded from the data because of the political factors, mentioned above. The regression of the overall balance $(O B)$ on the output gap ( $Y G A P$-the deviation of actual GDP from potential GDP expressed as a percentage of actual GDP) and the terms of trade (TOT) provides the following results ( $t$-statistics in brackets):

$$
O B=-6.3+0.293 Y G A P+0.075 \text { TOT. }
$$

These estimates show that the fiscal slippages observed are partly attributable to changes in the deficit related to the economic cycle and to fluctuations in the terms of trade. On average, a percentage point decline in growth, compared with the rate of potential growth, would widen the deficit by about 0.3 percent of GDP, which is not negligible. For the terms of trade, this effect would be on the order of 0.08 percent. However, as we shall see below, the variability of the terms of trade for most countries is much larger than for the output gap. The magnitude of these automatic stabilizers, which varies from one country to the next, points to the need to have 
Figure 3. Budget Balance, GDP Growth, and Changes in the Terms of Trade
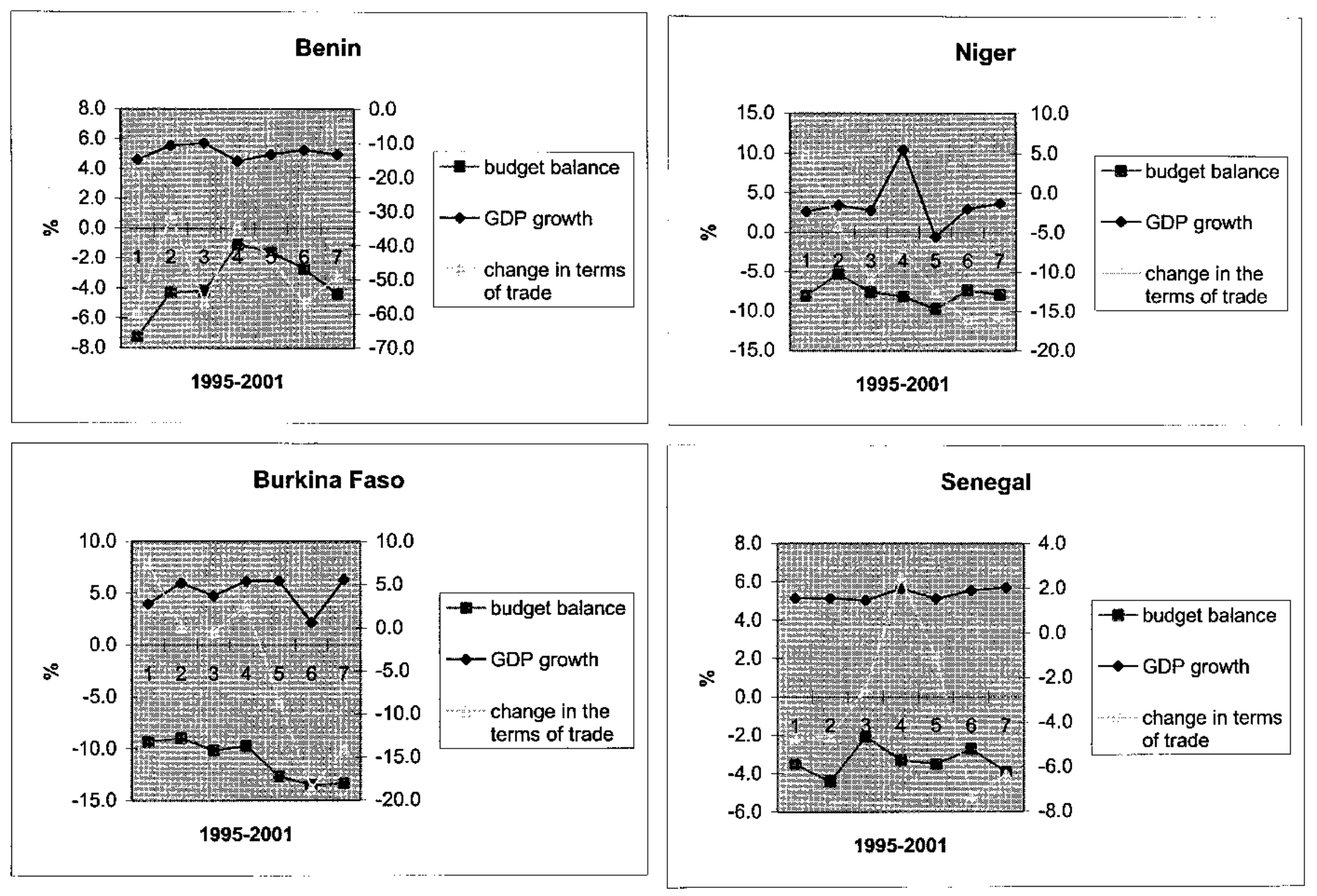

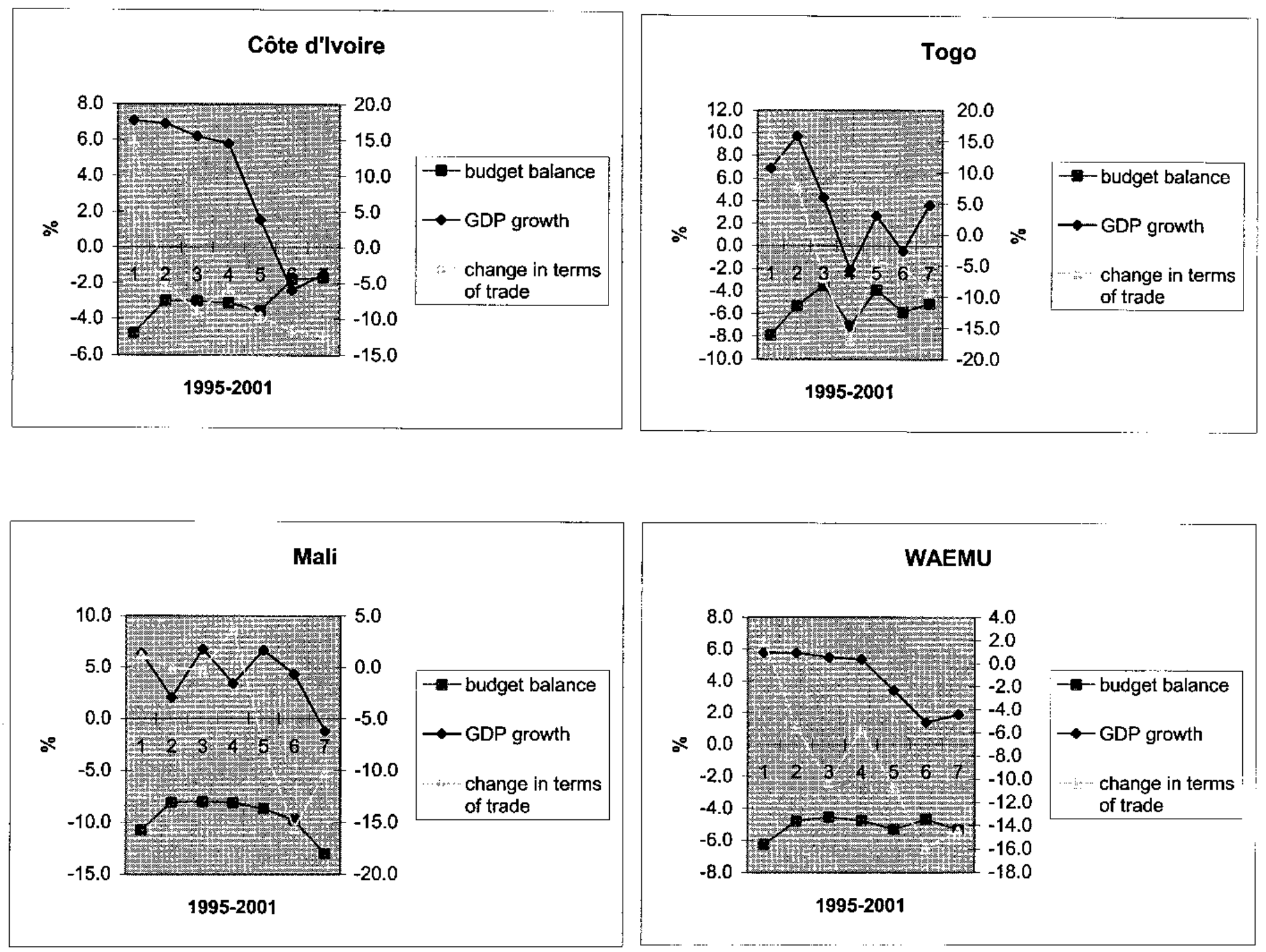
a minimum degree of flexibility for adapting fiscal policy to take account of exogenous shocks. In the event of an asymmetric temporary shock (affecting the dollar rate, the prices of raw materials, etc.), fiscal accommodation of these short-term developments may be necessary through the free play of a countercyclical fiscal policy, and fiscal norms should allow for that possibility. What this means-especially for countries whose public revenues are particularly volatile because of their heavy reliance on one or two raw materials-is that the government should make every effort to generate large fiscal surpluses in years when positive shocks occur and use them to dampen the restrictive effects of periods of economic downturn.

The analysis can be taken further by arguing that the imposition of strict fiscal rules in the WAEMU context is inimical to the smoothing of business cycles fluctuations. This is true insofar as monetary policy cannot absorb asymmetric shocks to the various economies, the mobility of factors is limited, and the Union does not yet have a system of taxes and transfers for mitigating shocks.

We, therefore, propose that the structural deficit concept, borrowed from industrial countries, be extended beyond cyclical adjustment to include a correction for the terms of trade. In light of the estimated effects on developments in the countries' fiscal positions, the correlations calculated above can be used to "adjust" the fiscal balance to take account of both of these factors. The resulting estimates of structural deficits suggest that member countries' performance did not deteriorate as much as indicated previously. Figure 4 shows that there were sizable movements in the terms of trade in the WAEMU over the period 1995-2001, with a tendency toward deterioration, whereas the cyclical effect was less strong. Developments in the context of a deficit that has been adjusted to take account of cyclical effects and the terms of trade are more positive than those of an unadjusted deficit.

Moreover, in the calculation of the fiscal balance for the WAEMU as a whole, weighted to take account of the GDP level for each member country, the overall budget deficit, excluding grants, seems to have shrunk during the period 1995-2001. An adjustment to take account of cyclical conditions and the terms of trade gives an even more positive picture of convergence. However, this picture is misleading and is caused by the large share of Côte d'Ivoire, which, as we have seen, should be excluded from the study for the period 1999-2001, along with Togo. As was the case with an unweighted average, a weighted average covering all the countries except Côte d'Ivoire and Togo shows a deterioration over the period 1995-2001, despite the adjustment made to take account of cyclical conditions and the terms of trade (Figure 5).

Another important issue concerns the source of cyclical changes in fiscal balances. In the industrial countries, it is assumed that cyclical effects are primarily the result of revenue changes. Indeed, observations show that in positive economic circumstances that boost earnings from capital and labor, tax revenue increase while expenditure rises less (or falls, for example because of the decline in unemployment benefits). For developing countries in general, however, Talvi and Végh (2000) provide some evidence that fiscal deficits may vary countercyclically, not procyclically. For the WAEMU countries, our evidence given above equation (1) suggests that deficits vary procyclically, but this does not seem to come from the revenue side, as instead we find a negative coefficient when regressing revenue on the output 


\section{Figure 4. WAEMU: Cyclical Position and Terms of Trade}

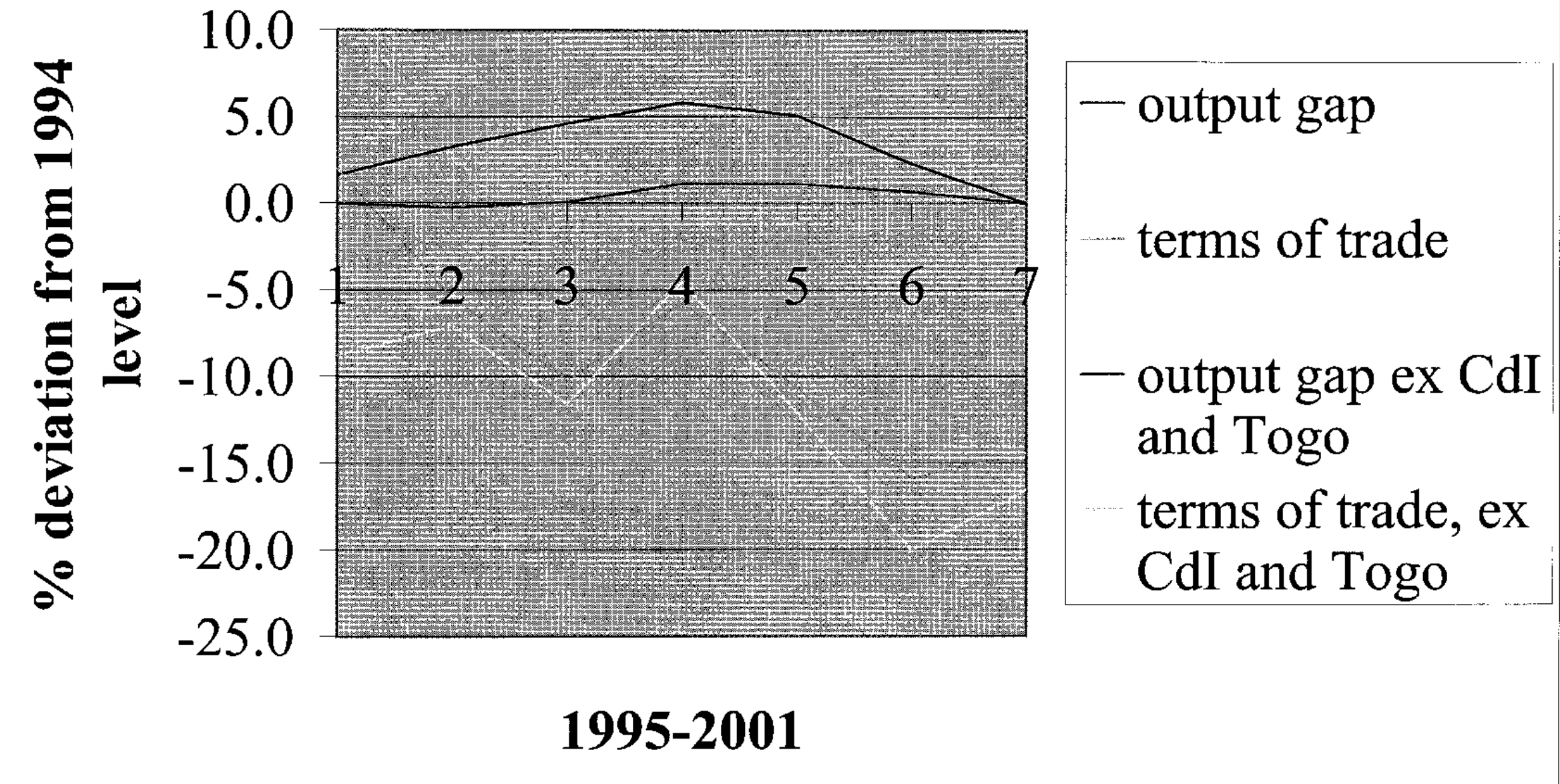




\section{Figure 5. WAEMU: Effects of Cycle and Terms of Trade on Budget Balance}

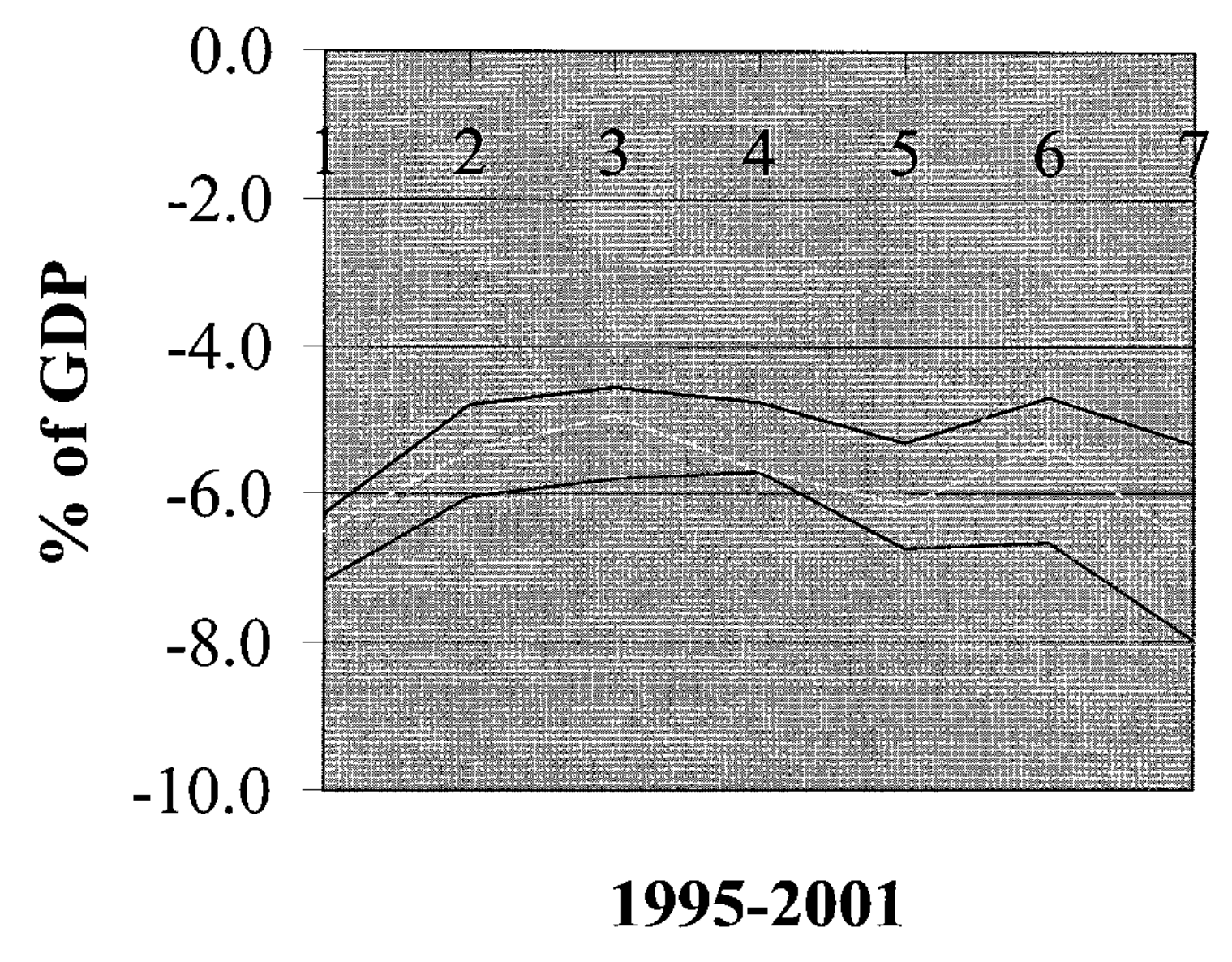

- budget balance

- corrected budget balance

- budget balance ex CdI and Togo

corrected budget balance, ex CdI and Togo 
gap. ${ }^{4}$ By contrast, there are strong cyclical effects on expenditure, which rises when the cycle is negative and the terms of trade are favorable. Indeed, a regression with panel data provides the following results:

$$
E X P=20.6-0.339 Y G A P-0.112 T O T
$$

Therefore, cyclical effects and terms of trade shocks seem to have a sizable impact on public expenditure. However, a country-by-country examination is needed to identify the source of these correlations - automatic stabilizers or discretionary expenditure. It would also be important to see which expenditure components are affected by the cycle and which by the terms of trade. It is worth noting that cyclical changes are not completely independent of economic policies. In addition, if changes in the terms of trade are permanent rather than temporary, a fiscal adjustment will be needed.

\section{Does the Elimination of Monetary Assistance Have Implications For Maintenance of Fiscal Discipline Within the UNion?}

It is difficult to determine whether the planned elimination of the flow of monetary financing from the BCEAO to the national treasuries will have a noticeable impact on fiscal adjustment efforts within the WAEMU. The response depends, to a certain extent, on the direction of the causality between financing and adjustment efforts. Studies carried out in the WAEMU context ${ }^{5}$ show that the causality is unidirectional for some countries, moving from resources to expenditure (Burkina Faso and Senegal) and from expenditure to resources (Benin and Togo), and bidirectional for Côte d'Ivoire and Mali. The implication of this analysis is that, for some but not all countries of the zone, a constraint on financing may well lead to expenditure adjustments.

Clearly, the countries concerned do not have direct control over the external financing of their deficits, which tends to be concessionary rather than commercial in nature. Financing based on the accumulation of payment arrears is not allowed in the context of the regional convergence pact, because the nonaccumulation of payment arrears is a first-order criterion that must be met by member countries. In addition, the use of this form of financing would curtail economic development and should in any case be avoided because it jeopardizes confidence in the ability of the economic players to fulfill their obligations. Extcrnal payment arrears are also generally

\footnotetext{
${ }^{4}$ A positive correlation may have been skewed by the tax and customs reforms that were made within the Union and that pushed revenue downward over this period. It may also be the case that specific rather than ad valorem taxes on primary commodities cause the revenue ratio to decline in booms and increase in slumps.

${ }^{5}$ See Doré and Nachega (2001).
} 
penalized through the suspension of financial disbursements by donors and lenders, as shown in the case of Côte d'Ivoire over the past two years.

Finally, with the current monetary policy guidelines aimed at fully eliminating monetary assistance from the BCEAO, the governments now have as alternative financing sources only the financial markets, through public issues. Such a financing method will require them to establish their creditworthiness through sustained adjustment efforts. Also, in light of the savings constraint in the Union and because the regional financial market is not an emerging market that is able to attract foreign investors, the financing of public deficits in this manner will certainly have a crowding-out effect on private investment. Hence, the need to monitor this financing method. ${ }^{6}$ Also, problems of access to the various financing methods can often lead to fiscal adjustments of lesser quality. ${ }^{7}$ The example of Côte d'Ivoire in 2001 illustrates this point. Following its sociopolitical crisis, Côte d'Ivoire was unable to obtain external financing and alternative financing (monetary or nonmonetary), since it was required within the framework of both regional surveillance and its interim arrangement with the IMF (a staff-monitored program) not to accumulate new arrears; as a result it was forced to adjust by substantially reducing its capital expenditure.

\section{What Leeway is There for ACHIEVing the Deficit ObJeCtive in The Future?}

It is helpful to break down the deficit into its various components to determine what can be done to remedy the slippages observed. The breakdown of the basic fiscal balance is also instructive because it allows for a link to be established between this first-order criterion and the secondary criteria. In practice, this balance has largely mirrored the overall balance, excluding grants, since 1994. The basic fiscal balance as a percentage of GDP $(B)$ can be written as follows:

$$
B=R+N-S R-I R-r D_{-1}-A,
$$

where $R=$ tax revenue as a percentage of GDP; $N=$ nontax revenue as a percentage of GDP; $S=$ the ratio of wages and salaries to tax receipts; $I=$ the ratio of domestically financed investment to tax receipts; $r=$ the interest rate on government debt; $D=$ government debt as a percent of GDP; and $A=$ other expenditure, as a percentage of GDP. We also note that changes in the stock of debt, as

\footnotetext{
${ }^{6}$ One approach could be to establish ceilings on bond issues by governments as performance criteria in country programs.

${ }^{7}$ Alesina and Perotti (1996) have shown that fiscal adjustments of good quality are those based on cuts in primary current expenditure (transfers and the wage bill), rather than in capital expenditure.
} 
a percentage of GDP, depend on the fiscal balance (in the absence of valuation effects, including those resulting from debt-reduction agreements):

$$
\Delta D=-B-g * D_{-1}
$$

where $g$ is the GDP growth rate. The evolution of the debt ratio is therefore largely determined by the government's success in containing the deficit and enhancing growth. Moreover, the ceilings on revenue, wages, and the level of public debt clearly help to observe the deficit ceiling. By contrast, the floor on domestically financed investment as a percentage of GDP can have effects that are contrary to the objective sought: if a government keeps its investment high, it will have to make greater efforts with respect to the other criteria to observe the deficit ceiling.

During the stability phase of the WAEMU convergence process, which is set to start in 2003, member states are expected to observe all the fiscal norms set in the convergence pact. With the ratio of the wage bill to tax revenue at 35 percent, the ratio of domestically financed investment to tax revenue at 20 percent, and the tax-to-GDP ratio at 17 percent, the wage bill would have to total less than 5.9 percent of GDP $(0.35 * 0.17 * 100)$, and the level of domestically-financed investment would represent at least 3.4 percent of GDP $\left(0.20^{*} 0.17^{*} 100\right)$. Based on equation (3) and assuming that interest payments as a percentage of GDP could be reduced to a level corresponding to the average nontax revenue-to-GDP ratio over the past three years (i.e., about 2 percent), ${ }^{8}$ observance of the key criterion on the basic fiscal balance (i.e., a nonnegative basic fiscal balance) would imply that other expenditure $(A)$ should represent at most 7.7 percent of GDP. This level partly includes social expenditure and all other nonpersonnel operating expenditure (transfers, subsidies, equipment, etc.).

It is noteworthy that, for most of the WAEMU countries, investment spending and social expenditure are items that can hardly be cut. In addition, the interest on public debt is a variable that is largely beyond government control. For investment, as stressed previously, there is a (second-order) criterion that tends to push this item upward (or at least to keep it from declining), which is also a reflection of the WAEMU countries' real infrastructure needs. Lastly, the objective of poverty reduction, to which governments, international institutions, and donor countries are giving increasing importance, would make a reduction in social expenditure highly unlikely. Capital and operating expenditure in the social sectors can be made more efficient, but not to the point of justifying cuts in the budget amounts allocated to them.

The government wage bill and the "compressible" component of other operating expenditure (subsidies and transfers other government current expenditure) thus seem to be the only fiscal

\footnotetext{
${ }^{8}$ This assumption can be made, given that all the countries involved are eligible for the Initiative for Heavily Indebted Poor Countries (HIPC Initiative). The size of the relief is of no relevance to our analysis, for it can be assumed that any reduction larger than that envisaged here would contribute to a related increase in social expenditure.
} 
adjustment variables. Although wage bill adjustments are possible, it is not entirely clear that there is room for sufficient reductions. Indeed, assuming that the countries maintain their wage ceilings at the current levels, all the countries except Togo and Guinea-Bissau would be in conformity with the regional convergence norms, if the efforts made to raise revenue were to result in the observance of the norm on the tax revenue-to-GDP ratio. As we have already stressed, few countries are currently able to meet the wage bill criterion because of the low level of their tax receipts (denominator). This underscores the need to increase tax revenue, which currently averages about 15 percent of GDP, compared with the convergence norm of 17 percent.

Given the difficulties of reducing several expenditure items (wages, domestically financed capital spending, interest payments, and social spending), it would seem advisable for countries to ensure that all other operating expenditure is limited to 7.7 percent of GDP. In the event of a shortfall in revenue as a result of exogenous shocks, these components of spending could be adjusted further down; alternatively, priority could be given to observing the criterion of reducing the share of government wages and salaries, so as to keep the level of other operating expenditure at above 7.7 percent of GDP.

Although the sensitivity of revenue to cyclical conditions and other exogenous shocks is not revealed in the model estimated here, the substantial change in revenue over time is proof that a mechanism is needed to stabilize revenue, in an effort to reduce the vulnerability of government finance to external shocks in the medium term. Such a mechanism would encourage fiscal discipline and strengthen the multilateral surveillance exercise while reserving a portion of fiscal resources for use in economic downturns.

\section{Summary}

Despite considerable progress, the WAEMU's experience in the area of fiscal convergence has produced mixed results since the 1994 devaluation. After an initial period of robust growth and fiscal consolidation, a marked deterioration of the fiscal balance was observed in most of the countries after 1997. Unfavorable terms of trade developments have undoubtedly had a negative impact on growth and budget balances, but in several countries economic policies have been the main cause of the fiscal slippages, which have hindered the achievement of strong, sustained growth within the Union.

The elimination of statutory advances by the BCEAO, already approved more than three years ago by the WAEMU Council of Ministers, makes it all the more necessary to pursue adjustment efforts, with a view to reducing budget deficits to levels consistent with the regional convergence norms. The above analysis suggests that the credibility of multilateral surveillance would be further strengthened if the deficit were adjusted to take account of the effects of temporary changes in cyclical conditions and in the terms of trade. This approach would provide governments with a minimum of elbow room to adapt their fiscal policies to take account of exogenous shocks. However, account should no doubt be taken of the effects on growth brought about by economic policies themselves, as well as of the fact that some changes in the terms of trade are not temporary and should therefore lead to fiscal policy adjustments. 
The analysis also suggests that, for governments to meet the fiscal convergence standards, they will have to pay more attention to the criteria of reducing the share of public wages and of monitoring other operating expenditure. It further suggests that, in light of the limited scope for reducing expenditure in a context of poverty reduction efforts, it would be helpful to focus on the quality of fiscal adjustments and on the fiscal revenue ratio. Such a focus would mean streamlining expenditure (for instance, better redeploying of civil service staff) and engaging in sustained revenue-raising efforts. 


\section{Panel Regressions for WAEMU's Fiscal AdJUSTMENT}

\section{Cyclical and terms of trade adjustment}

In order to adjust for the cycle, an estimate of the output gap was calculated for each country by cumulating (from zero in 1994) its annual rate of real GDP growth minus its average over 1995-2001. Similarly, the changes in the terms of trade were cumulated from zero in 1994 (but the mean was not subtracted).

The actual overall deficits were regressed on measures of the cycle and the terms of trade for seven of the countries of WAEMU (all except Guinea-Bissau), from 1995-2001, using a panel with fixed effects. The observations for Côte d'Ivoire and Togo for 1999-2001 were omitted from the regressions because of political turmoil in those countries. The deficit was regressed on both the change in GDP and terms of trade, and their on their cumulated values (described above). The cumulated variables were most significant. Fixed effects are equivalent here to including separate country intercepts.

The result of the estimation is given in Table A2. Both the cycle and the terms of trade are significant. The relative importance in explaining the deficit varies from country to country. For instance, for Benin the terms of trade movements have been very large, and, hence, that variable dominates the cyclical correction. For Côte d'Ivoire, the opposite is true.

\section{Effect on expenditure and revenues}

In industrial countries, revenues vary with the cycle and explain most of the countercyclical variation in the deficit; this situation reflects the role of fiscal policy as an automatic stabilizer. In principle, expenditures can also vary countercyclically, as such items as unemployment insurance payments increase in times of recession, but the cyclical behavior of revenues is the main driving force behind movements in the deficit.

Some literature suggests that suggests that such fiscal policy has a very different role for developing countries (e.g., Talvi and Végh, 2000). Table A2 reports panel regressions of government total revenues on the cycle and the terms of trade. Contrary to industrial countries, these do not seem to vary procyclically - higher activity or positive terms of trade shocks do not, over this sample period, produce significantly higher revenues. Instead, the countercyclical variation of the deficit (see above) comes from a countercyclical variation of government expenditures: in bad times, the government spends more (Table A3), and this produces a widening of the deficit. This outcome may be explained by transfers that vary with the cycle or with the terms of trade-for instance, subsidies to the cotton sector. More detailed data would be needed to identify the sources of the fiscal role in countering shocks. 


\section{Correlation between real GDP and the terms of trade}

Since many of the countries in the region are strongly dependent on one or several primary commodities, it is interesting to see whether GDP growth is primarily driven by the terms of trade. Table A4 shows that this is not the case. These results suggest that over 1995-2001 (with certain observations for Côte d'Ivoire and Togo excluded for the reasons given above), that there is no significant effect of changes in the terms of trade on the rate of GDP growth, or of the level of the terms of trade on the output gap. Thus it is justified to include both variables in equations for the fiscal balance. 
Table A1. WAEMU ${ }^{1}$ : Panel Regression of Fiscal Balance (Ratio to GDP) on Output Gap and Terms of Trade, 1995-2001 ${ }^{2}$

Fixed effects (within) regression

Group variable (i): code

$\underline{R}$-sq: within $=0.2218$

between $=0.0026$

overall $=0.0046$

$\operatorname{corr} \underline{(u, i, X b)}=-0.5662$

$\begin{array}{rll}\text { Number of obs } & = & 43 \\ \text { Number of groups } & = & 7 \\ \text { Obs per group: } \min & = & 4 \\ \text { avg } & = & 6.1 \\ \max & = & 7 \\ & & \\ \underline{F}(2,34) & = & 4.85 \\ \text { Prob }>\underline{F} & = & 0.0141\end{array}$

Number of obs $\quad=\quad 43$

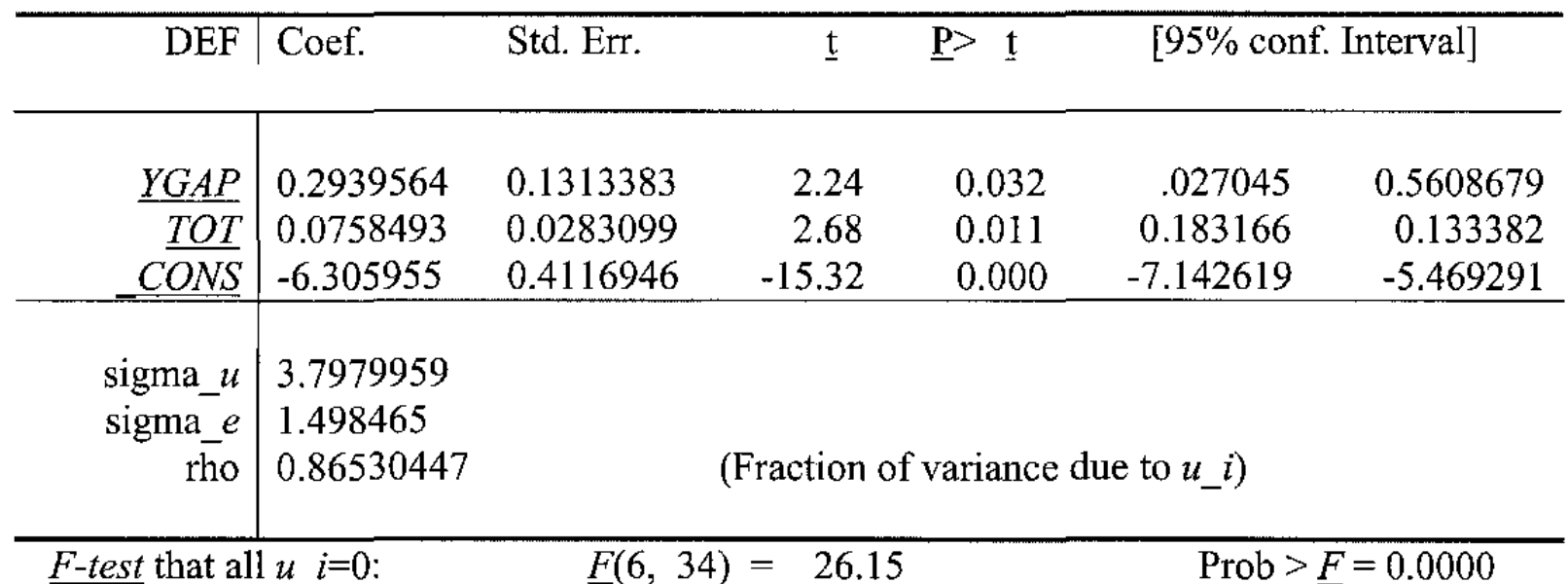

1/ Excluding Guinea-Bissau.

${ }^{2 /}$ Observations for 1999-2001 excluded for Côte d'Ivoire and Togo. 
Table A2. WAEMU': Panel Regression of Government Revenues (Ratio to GDP) on Output Gap and Terms of Trade, 1995-2001 2

Fixed effects (within) regression Group variable $(i)$ : code

$$
\begin{array}{ll}
\text { R-sq: } & \text { within }=0.0871 \\
\text { between } & =0.0433 \\
\text { overall } & =0.0054
\end{array}
$$

\begin{tabular}{|c|c|c|c|c|c|c|}
\hline $\mathrm{DEF}$ & Coef. & Std. Err. & & \begin{tabular}{l|l|}
$\mathrm{P}>$ & $\mathrm{t}$ \\
\end{tabular} & \multicolumn{2}{|c|}{ [95\% conf. Interval] } \\
\hline$Y G A P$ & -0.0452888 & 0.0917907 & -0.49 & 0.625 & 0.23183 & 0.1412524 \\
\hline TOT & -0.0356357 & 0.0197855 & -1.80 & 0.081 & -0.0758446 & 0.0045732 \\
\hline$\widehat{C O N S}$ & 14.30594 & 0.2877284 & 49.72 & 0.000 & 13.7212 & 14.89067 \\
\hline sigma_u & 4.2033001 & & \multirow{3}{*}{\multicolumn{4}{|c|}{ (Fraction of variance due to $\mathrm{u}_{-} \mathrm{I}$ ) }} \\
\hline sigma_e & 1.0472589 & & & & & \\
\hline rho & 0.94155175 & & & & & \\
\hline
\end{tabular}

corr(u_i, Xb) $=-0.2629$

$\begin{array}{rll}\text { Number of obs } & = & 43 \\ \text { Number of groups } & = & 7 \\ \text { Obs per group: } \min & = & 4 \\ \text { avg } & = & 6.1 \\ \max & = & 7 \\ & & \\ F(2,34) & = & 1.62 \\ \text { Prob }>\underline{F} & = & 0.2124\end{array}$

1/ Excluding Guinea-Bissau.

2/ Observations for 1999-2001 excluded for Côte d'Ivoire and Togo. 
Table A3. WAEMU ${ }^{1:}$ Panel Regression of Government Expenditures (Ratio to GDP) on Output Gap and Terms of Trade, 1995-2001 ${ }^{2}$

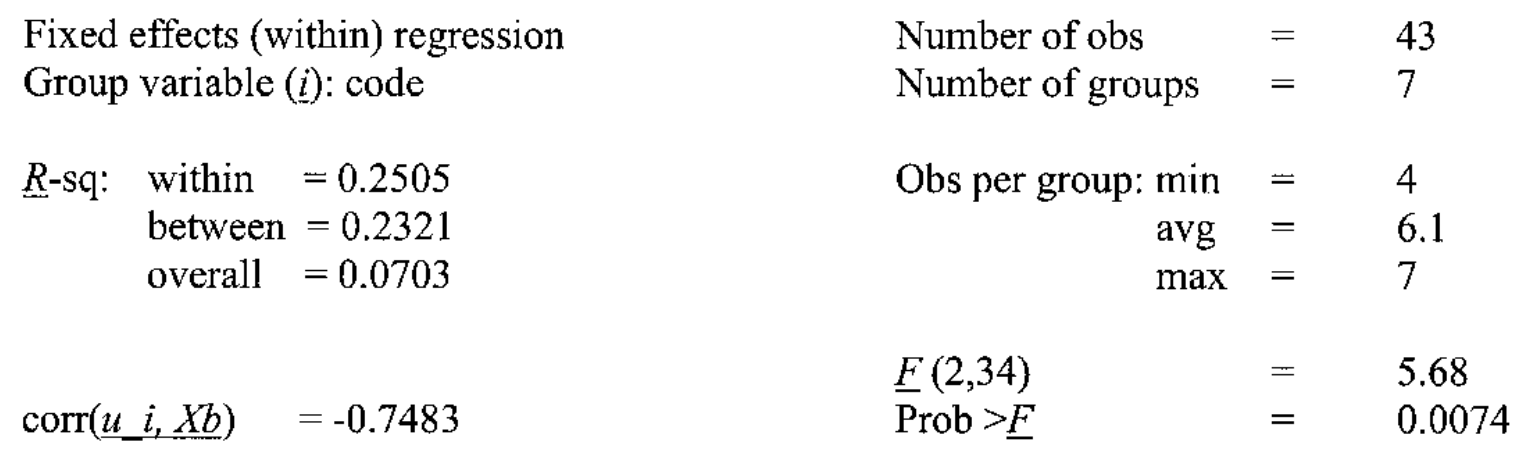

\begin{tabular}{|c|c|c|c|c|c|c|}
\hline $\mathrm{DEF}$ & Coef. & Std. Err. & t & $P>|t|$ & \multicolumn{2}{|c|}{$[95 \%$ conf. Interval $]$} \\
\hline$\underline{Y G A P}$ & -0.3393732 & $\begin{array}{l}0.165710 \\
4\end{array}$ & -2.05 & 0.048 & -0.6761373 & -0.0026091 \\
\hline$\underline{T O T}$ & -0.1116187 & $\begin{array}{l}0.035718 \\
8\end{array}$ & -3.12 & 0.004 & -0.1842081 & -0.0390293 \\
\hline$\underline{C O N S}$ & 20.61155 & $\begin{array}{l}0.519438 \\
1\end{array}$ & 39.68 & 0.000 & 19.55593 & 21.66718 \\
\hline sigma_ $\underline{u}$ & 5.1421178 & & \multirow{3}{*}{\multicolumn{4}{|c|}{ (Fraction of variance due to $\underline{u} i$ ) }} \\
\hline sigma_e & 1.8906241 & & & & & \\
\hline rho & 0.88091421 & & & & & \\
\hline
\end{tabular}

${ }^{1 /}$ Excluding Guinea-Bissau.

${ }^{2 /}$ Observations for 1999-2001 excluded for Côte d'Ivoire and Togo. 
Table A4. WAEMU ${ }^{1:}$ Correlation Between Rate of Change of Output and Rate of Change of Terms of Trade, 1995-2001

\begin{tabular}{lc}
\hline Country & Correlation coefficient \\
\hline Benin & 0.023 \\
Burkina Faso & 0.221 \\
Côte d'Ivoire & 0.061 \\
Mali & -0.552 \\
Niger & 0.510 \\
Senegal & 0.225 \\
Togo & 0.179 \\
WAEMU (weighted) & -0.064 \\
\hline
\end{tabular}

${ }^{1 /}$ Excluding Guinea-Bissau. 


\section{REFERENCES}

Alesina, Alberto, and Roberto Perotti, 1996, "Fiscal Adjustments in OECD Countries: Composition and Macroeconomic Effects," NBER Working Paper No. 5730 (Cambridge, Massachusetts. National Bureau of Economic Research).

Doré, Ousmane, and Jean-Claude-Nachega, 2000, "Budgetary Convergence in the WAEMU: Adjustment Through Revenue or Expenditure?" IMF Working Paper 00/109 (Washington: International Monetary Fund).

Talvi, Emesto, and Carlos A. Végh, 2000, "Tax Base Variability and Procyclical Fiscal Policy," NBER Working Paper No. 7499 (Cambridge, Massachusetts: National Bureau of Economic Research). 